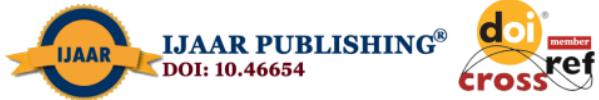

International Journal of Advanced Academic Research (Business and Economic Development) | ISSN: 2488-9849

Journal DOI: 10.46654/ij.24889849

Vol. 6, Issue 11 (November, 2020)|www.ijaar.org

Article DOI: 10.46654/ij.24889849.b61117

\section{INNOVATION STRATEGIES AND ORGANIZATIONAL PERFORMANCE OF WATER PACKAGING FIRMS IN LAGOS STATE}

\author{
Omoruyi Eke \\ Department of Management, \\ University of Port Harcourt Business School, Port Harcourt, Nigeria \\ Omoruyieke@gmail.com \\ B. Chima Onuoha \\ Department of Management, \\ University of Port Harcourt, Choba, Port Harcourt, Rivers state, Nigeria
}

\begin{abstract}
This study investigated innovation strategies and organizational performance of water packaging firms in Lagos State, Nigeria due to the seeming dearth of studies on the topic. Crosssectional research design methodology was used in collecting data from 118 water packaging firms in Lagos State. The hypotheses were analyzed with Kendall's Tau-b correlation coefficient (denoted $\tau$ ) by means of Statistical Package for Social Sciences (SPSS) Version 27. Results suggest that higher levels of innovation strategies (aggressiveness- $\tau=0.658, p=.003$; defensiveness- $\tau=0.535, p=.001$; futurity- $\tau=0.736, p=.003$; proactiveness- $\tau=0.877, p=$ .000) amplify organizational performance. The study recommends that management of water packaging firms should ensure innovation strategies supersede profit making and give more attention to potential and prospective customers as they develop the quality and performance of their product.
\end{abstract}

Keywords: Innovation Strategies, Aggressiveness, Defensiveness, Futurity, Proactiveness and Organizational Performance 


\section{INTRODUCTION}

\subsection{Universality of Water}

Water is the most consumed beverage globally. This is particularly due to its uniqueness as a necessary tonic for the sustenance of human life. Water also exists naturally and abundantly flows through a large portion of the Earth's surface and sub-surface.

However, for water to be deemed suitable for human consumption, it usually needs to be purified and made safe for consumption.

A famous Nigerian singer and social critic, Late Fela Anikulapo Kuti sang in one of his songs: 'water no get enemy'. In this hit song, Fela highlighted the various uses of water; including its consumption as a necessity for human survival. This song goes a long way to highlight the criticality and universality of water to the varied needs of Man.

\subsection{Organizational Performance}

The notion of organizational performance is affiliated with the success of an organization (Brynjolfson, 1993). Organizational performance enhances the ability of an enterprise to accomplish its mission through sound management, strong governance and a persistent dedication in achieving specific goals over a given period (Stafford \& Miles, 2013).

Previous studies by Upadhaya, Munir \& Blount (2014) submitted that organizational performance is vital in keeping an organization afloat. Similarly, Banafa, Muturi \& Ngugi (2015) postulated that organizational performance is a key player in the increase of the market value of an organization.Furthermore,Choi (2002) and Payal, Ahmed \& Debnath (2019) decomposed organizational performance intomarket share, growth andprofitability.

\subsection{Innovation}

Every innovation strategy ought to align with the mission, vision, goals and objectives of an organization (Karabulut, 2015). According to Gilbert (1994), innovation strategy refers to the extent to which innovation is used to foster organizational performance.Katz, B. R., \& Preez, N. D., \& Schutte, C. S. L. (2010) defined innovation strategy as the entirety of strategic options an organization makes regarding its innovative pursuit. Innovation strategy plays an important role in developing organizational precedence and supply-chain actions (Celtekligil \& Zafer, 2019).

The dimensions of innovation strategies used for this study are: Aggressiveness, Defensiveness, Futurity, and Proactiveness (Venkatraman, 1989; Morgan \& Strong, 1998). 
Many prior studies on innovation strategies and other constructs abound. For instance, Literature is replete with write-ups on IT adoption and other constructs and sectors. For instance, there exists literature on information and technology (Akman\& Yilmaz, 2008), on manufacturing (Karabulut, 2015), on competitive advantages (Gërguri, Rexhepi \& Ramadani, 2013) and on organizational performance (Odumeru, 2013).

However, only a few numbers of previous studies have focused on 'innovation strategy and organizational performance in the manufacturing sector' (Karabulut, 2015); particularly the Nigerian context (Odumeru, 2013). Thus, these gaps as pointed out above, made it an imperative to investigate the 'relationship between innovation strategies and organizational performance of water packaging firms in Lagos'.

\subsection{Lagos Water Scene}

In Lagos State, the public water works set up by the government for extraction and purification of water has been out of service for decades. As with many other public infrastructures across the length and breadth of various developing countries, the water works in Lagos State has been in a state of decay for many decades.

Hence, safe drinking water is typically made available to residents of Lagos State by the efforts of private entrepreneurs who have set up businesses which commercially extract, purify and package water for public consumption.

Enekwe, Okwo \& Ordu (2013) stated that due to high costs of production and the prevailing macroeconomic conditions across the country; many water packaging firms in Lagos have performed far below expectation in terms of profitability. Pearce \& Robinson (2003) also observed that an increase in these components can be equated with success, whereas a decrease in them is a manifestation of unfavorable actions by firms and usually equated with failure (poor performance).

Water packaging firms, like other businesses around Lagos State, have in recent times been experiencing unstable organizational performances due to a myriad of socio-economic, political and other dynamic business challenges. These performances have challenged the very existence of these businesses and have often totally eroded their profitability (poor profit margin), as well as led to low market share and slow growth (Engum, 2009; Cherry, 2012). These in effect eroded the original essence of setting up the business in the first place.

Sub-optimal performance has been one of the many problems disturbing water packaging firms in Lagos State and the inability to grasp it has resulted in the extinction of several firms. This has also affected the capacity of firms to cope within the industry in order to achieve optimal levels of performance (Onwughalu, Okeke \& Henry-Chibor, 2017). 
Notwithstanding the efforts mentioned above, water packaging firms in Lagos State are still performing below their expectation. According to Ademola (2012), most firms rely on "emergency" power generators to execute operations, adding to their costs. Not forgetting other regulatory issues, multiple taxes and trade facilitation issues, etc.

\subsection{Winning Strategies in a Competitive Water Packaging Industry}

1. Firms must continually aim at: Profitability, Growth, Business Sustainability and Continuity.

2. Firms Must Eliminate Price Wars - Forming a marketing union could help bring sanity to the industry and help introduce realistic pricing models agreeable and enforceable to all firms in the industry.

3. Firms Must Drive Cost Efficiency - Adopting operating cost reduction measures like searching for the cheapest \& renewable sources of power for their production line; operating a performance-based commission strategy for staff salary payments; source production materials from original manufacturers rather than middlemen, etc.

4. Firms Must Defend Their Brand - Image is everything. Hence, ensure the product look and feel stands out and always entices the customer to select yours in an array of similar products. Having an effective management and governance structure will portray a firmas one worthy of doing business with.

5. Firms Must Maintain Their Product Quality - Crisp packaging, clear water colour, pure quality of the water products is crucial. Watch and monitor trends and customer preferences and solicit customer feedback for product improvement and new tastes.

6. Firms Must Provide Complementary Services/Products - Expand target customer segment to ensure you are providing products and services to a varied array of customers than competition. Be a 'One Stop Shop' by providing other complementary products and services e.g. Ice Cubes, Delivery services, Flavoured Water, carbonated drinks.

7. Firms Must Provide First-Class Customer Services - Neatly dressed and courteous staff handling operations; prompt marketing and delivery crew. Clean and properly handled products at delivery, etc.

8. Firms Must Gather Business Intelligence - Collect customer data and churn out useful information to aid in forecasting trends of consumption and product preferences. Use of a predictive supply/delivery schedule based on agreed 'Replenishment Point'.

\subsection{Conceptual Framework}

O'Regan (2002) submitted that firms with increased market share, growth and profitability behave very differently from firms with a perceived decrease in these components. According to O'Regan, a rise in turnover on investment is the expected output of higher market share due to the firms' growth (increasing size and resources) and it leads to a higher rate of performance. 
In the same vein; Oke, Walumbwa \& Myers (2012) reverberated that manufacturing firms in Nigeria encounter poor performance as a result of low market share, stunted growth and poor profit margin.

In all, it seems that water packaging firms in Lagos State are not deploying the requisite innovation strategies that will create a surge in their performance. The series of performance inadequacies have required that a prompt investigation should be carried out to empirically interrogate the nexus between innovation strategies and organizational performance of water packaging firms in Lagos State in order to arrive at recommendations.

Based on the foregoing, the study provides a conceptual framework (operational model) which incorporates the way the research problem could be undertaken (Liehr \& Smith, 1999).

\section{Conceptual Framework:}

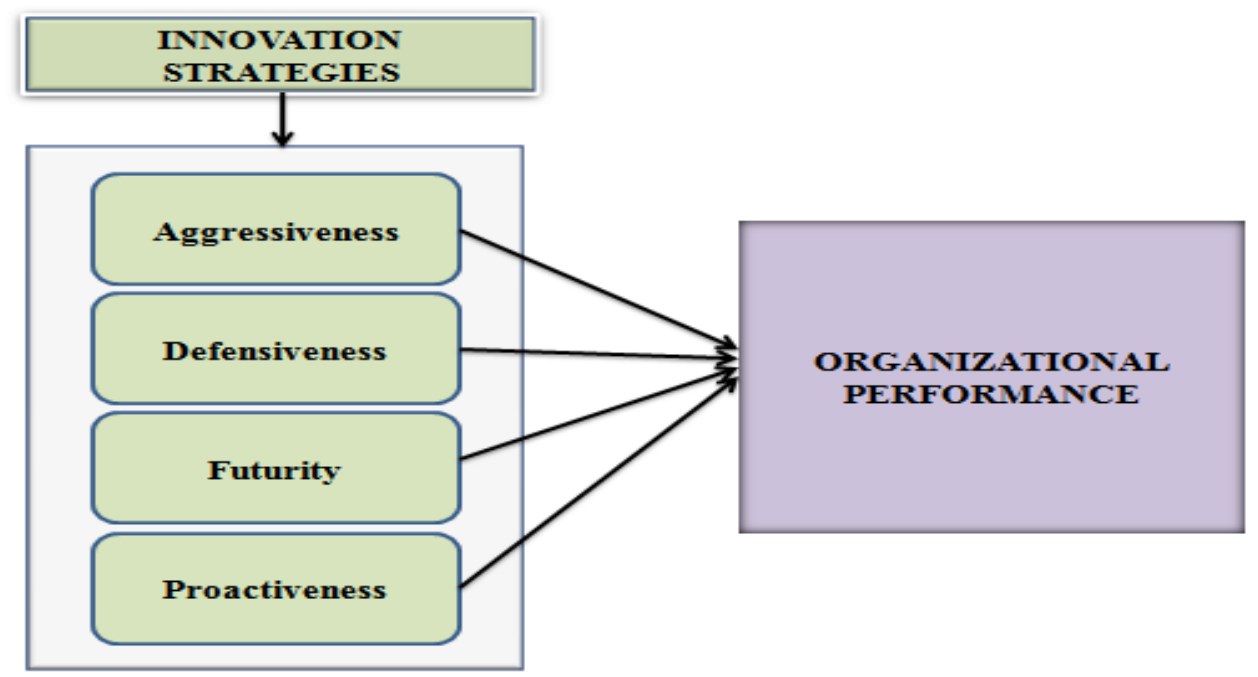

Figure 1 


\section{Hypotheses:}

The hypotheses for this study are formulated as follows:

Ho1: There is no correlation between aggressiveness and organizational performance.

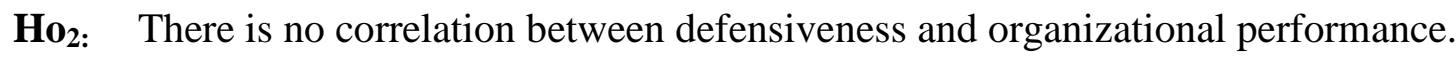

Ho3: There is no correlation between futurity and organizational performance.

Ho4: There is no correlation between proactiveness and organizational performance.

\section{LITERATURE REVIEW}

\subsection{Baseline Theories}

\subsubsection{Dynamic Capabilities Theory}

Teece, Pisano \& Shuen (1997) argued that organizations depend on dynamic capabilities to build competitive advantage in regimes of rapid change. Dynamic capability is the ability of an organization to purposefully adapt to its resource base. Teece et al. (1997) defined the concept as 'the firm's ability to integrate, build, and reconfigure internal and external competences to address rapidly changing environments.'

The basic assumption of the dynamic capability's framework is that core competencies should be used to modify short-term competitive positions that can be used to build longer-term competitive advantage.

Dynamic capability theory posits that: since contemporary marketplaces are more dynamic than the simple heterogeneity in a firm's resource endowment; it is the capabilities by which resources of the firms are acquired and deployed in ways that match the firm's market environment that explains inter-firm performance variance (Teece et al., 1997).

Teece, Peteraf \& Leih (2016) also assert that strong dynamic capabilities are useful in achieving organizational performance. These capabilities are needed to withstand the deep uncertainty connected with typical entrepreneurial endeavour such as that which is generated by innovation and the accompanying dynamic competition.

\subsubsection{The Resource-Based View (RBV)}

Organizational performance falls within the sphere of the Resource-Based View. The ResourceBased View (RBV) has its origin in the work of Penrose (1959) and is further established by Barney (1991). 
The RBV of a firm postulate that: differences in firm performance occur when a firm possesses valuable resources that others do not have (Wernerfelt, 1984). Peteraf (1993); Makhija (2003) both conclude that the RBV of a firm is focused on managing the inside of the firm (its resources and capabilities) in order to improve the performance of the organization.

The RBV emphasizes on the concept of difficult-to-replicate features of the firm as sources for superior performance and competitive advantage (Hamel \& Prahalad, 1996). Similarly, Penrose (1959) and Barney (1991) suggest that the RBV is based on why some organizations are exceptional and the measures taken to improve on competitive advantage and performance over their competitors in the industry (Ahmed \& Othman, 2017).

When it comes to the relationship between innovation strategies and organizational performance the RBV offers a useful lens for understanding this connection. Basically, the RBV argues that "firms possess resources, a part of which enables them to attain competitive advantage and a further part which leads to superior long-term performance" (Wernerfelt, 1984, p.108).

Furthermore, Hoopes, Madsen \& Walker (2003) stated that this theory is applied to explain differences in performance within an industry. Helfat \& Peteraf, (2003) posited that through RBV a firm's resources are strengthened; its competitive capabilities improved, and performance enhanced. The RBV makes organizations accomplish superior performance by formulating strategies based on their internal capabilities (Henry, 2008).

\subsection{Organizational Performance}

According to Hendry (2012), performance in organizations is a multi-faceted concept whose complexity makes it difficult for it to be defined from a single perspective; due to the fact that performance is a multi-dimensional, organizational concept; which cannot be measured using a single measurement tool.

Choi (2002) opined that organizational performance is the ability of an organization to realize its goals (which leads to optimal performance).Dozier (2016) posits that organizational performance is the actual 'outcome' of an organization; measured against the set 'goals' or 'targets'. Thus, organizational performance plays a significant role as a catalyst to the development and economic growth of any organization (Devinney, Richard, Yip \& Johnson, 2005).

Venkatraman \& Ramanujam (1986) and Chenhall (2005) classified organizational performance into two categories namely: financial (economic) and non-financial (operational) performance.

Similarly, Upadhaya, Munor \& Blount (2014) noted that organizational performance consists of three specific areas of firm outcomes: (1) financial performance (return on assets, return on investment); (2) product-market performance (sales, market share); and (3) shareholder return (total shareholder return economic value added). 
This current study adopts both the financial and non-financial performance as indicators for organizational performance.

Market share is an indicator of super sales (Venkatraman \& Ramanujam, 1986); a significant indicator of market competitiveness (Armstrong \& Greene, 2007) and used as a benchmark for an organization against its competitors (Sarkissian \& Schill, 2010). It is a tool used by managers to evaluate what is attainable in their market (Sliden, 2014). Furthermore, it is used as a standard for evaluating total market growth; as well as trends in customers' selection among competitors (Daniel, 2018).

According to Davidsson, Achtenhagen \& Naldi (2010), growth is an important occurrence that portrays organizational performance. In the pursuance of growth, organizations expand their products or services; attract more customers; increase sales; and experience employee turnover (Achtenhagen, Naldi, \& Melin, 2010). Growth helps to reduce the prospect of organizations going into extinction (Rauch \& Rijskik (2013).

Profitability is the central objective of all firms (Myers, 2001). Profitability is necessary for an organization to maintain its operations (Abreu \& Mendes, 2002) and for its shareholders to obtain fair returns (Pasiouras \& Kosmidou, 2007). According to Yazdanfar (2013), it buffers performance in the long run and serves as an avenue for organizations to attract external capital from investors (Robinson, Henry, Pirie \& Broihahn, 2015).

\subsection{Innovative Strategies}

An innovation strategy ought to align with the mission, vision, goals and objectives of an organization (Karabulut, 2015). Katz, B. R., \&Preez, N. D., \& Schutte, C. S. L. (2010) defined innovation strategy as the entirety of strategic options an organization makes regarding its innovative pursuit.

According to Katz, Preez\& Schutte (2010), innovation strategy is a firm's guidelines about when and how it should selectively abandon the past and/or change its corporate strategy and objectives in order to focus on the business of the future.

Furthermore, Segaro, Larimo \& Jones (2014) opined that it is the philosophy and behavior of an organization directed towards comprehending the current and future needs of the market and responding to it.

Advocates of innovation strategy (Calantone, Cavusgil \& Zhao, 2002) argued that for better performance; distance should not be a barrier between organizations and their customers, and the competitors (Paladino, 2009). In supporting the notion, Calantone et al (2002) and Sandvik \& Sandvik (2003) also averred that organizations that intentionally concentrate on the market as the source of their innovation strategy will learn better and have an edge over their competitors. 
Anthony, Eyring \& Gibson (2006), in discussing the importance of innovative strategies submitted that: (1) It aligns innovation objectives with corporate objectives (2) It serves as a guideline on the type, level and impact of innovation required to achieve current corporate objectives (3) It allocates resources between current operations and innovation initiatives and (iv) It is used as the best proxy to utilize resources for innovation.

\subsubsection{Dimensions of Innovative Strategies}

\subsubsection{Aggressiveness}

Firms exhibit Aggressiveness through research and development. Resource dedication, investments and innovativeness point out Aggressiveness of a firm. Aggressiveness allows a firm to allocate its resources to improve market position at a relatively faster rate than its competitors. Aggressive firms are resolute to be market leaders (Venkatraman, 1989).

Aggressiveness measures the firm's ability to engage organizational resources in executing aggressive strategies and the pursuit of increased market share as a means of achieving business unit profitability. The aim of the firm is to possess higher market share ahead of competitors (Abiodun, 2009).

\subsubsection{Defensiveness}

Defensiveness echoes the magnitude of a firm's behaviour in protecting its market position and takes cognizance of their current customers (Venkatraman, 1989). Defensiveness makes firms to be conscious of current customer needs and wants related to current products.

This dimension emphasizes on the firm's defense strategies over its core technology and product-market domain using cost minimization and techniques that achieve operational efficiency (Miles \& Cameron, 1982; Özsomer, Calantone \& Benedetto, 1997)

\subsubsection{Futurity}

Futurity is the long-term plan of a firm towards their customers, competitors and environment (Vazquez, Santoz \& Alvarez, 2001). It is the extent to which decisions that relate to possible future occurrences are seriously engaged. Futurity reflects issues like sales forecast, changes in customer preference and tracking of the dynamic environment.

Futurity is manifested by a firm's incorporation of its vision as a strategic concern (Stambaugh, Yu \& Dubinsky, 2011). In this way, they could forecast possible changes and then they could transform these changes to innovations. Futurity helps firms to constitute a long-term horizon and provide a possibility to transform new and creative ideas and opportunities to innovations (Jaworski \& Kohli, 1996). 


\subsubsection{Proactiveness}

According to Bateman \& Crant, (1999), to be proactive is to alter things in an expected course to improve things. Proactiveness refers to the creation of new ideas and the influencing of innovative capability (Özsomer et al., 1997).

Proactiveness recognizes employees of the organization from those in the marketplace. Proactiveness helps firms gain market advantage and curb any situation that may arise, and also has a positive impact on the firm's innovative capability. Specifically, firms exhibit proactiveness in order to sustain their competitive advantages (Morgan \& Strong, 1998).

\subsection{Empirical Review}

Oduyoye, Akinlabi \& Gafar (2020) investigated entrepreneurial orientation (pro-activeness\& aggressiveness) and profitability of selected water packaging companies in Lagos State, Nigeria. Stratified random sampling techniques were adopted to arrive at a sample size of 554 employees using stratified, proportionate and random sampling techniques.

Multiple regression analysis was used for data analysis to analyze the data and test the hypothesis. Findings revealed a positive and significant effect of entrepreneurial orientation dimensions (pro-activeness \& aggressiveness) on profitability $\left(\mathrm{R}^{2}=0.165, \mathrm{p}<0.05\right)$. The authors concluded that entrepreneurial orientation dimensions magnify profitability of selected water packaging firms in Lagos State, Nigeria.

Thus, the study recommended that adequate attention be given to the implementation of the various dimensions of entrepreneurial orientation.

Karabulut (2015) empirically investigated how innovation strategy affects firm performance. A sample of 197 Turkish manufacturing firms was selected for the study. Multiple regression was explored for testing of the hypotheses. It was found that innovation strategy is positively correlated $(\mathrm{p}<0.05)$ with firm performance. However, innovation strategy has more impact on financial performance more than other dimensions of firm performance. The study concluded that adoption of an innovation strategy aids Turkish manufacturing firms to improve on their financial performance.

\section{METHOD \& ANALYSIS}

\subsection{Methodology}

This study adopts the quasi-experimental research design and the cross-sectional research design. The target population comprises of 170selected water packaging firms in Lagos State as obtained from the office of the Standards Organization of Nigeria (SON), Lagos State Office. 


\section{Article DOI: 10.46654/ij.24889849.b61117}

The Krejcie and Morgan table was adopted to determine the sample size which amounted to 118 water packaging firms. In keeping with this decision, 118 copies of the questionnaire were distributed to water packaging firms.

However, only 108 copies were retrieved, out of which only 99 were considered usable for analysis.

The methodology involved administering a Questionnaire to Operators or Managers of Water Packaging firms from across Lagos State (who were assembled at a Stakeholder Workshop convened to harmonize health and safety concerns and measures for Water Packaging Firms in Lagos state based on the prevailing COVID-19 pandemic).

Not every respondent approached was amenable to taking part in the survey and many others actually saw it as a ploy to obtain their proprietary information with a view to using the information gathered to erode their current real or perceived competitive advantage; and no amount of counseling that this was academic research could sway them away from their preconceived notion.

This analysis was conducted using Kendall's Tau-b correlation coefficient (denoted $\tau$ ) by means of Statistical Package for Social Sciences (SPSS)Version 27.

\subsection{Data Analysis}

Four hypotheses were formulated and tested as follows:

$\mathrm{Ho}_{1}$ :There is no correlation between aggressiveness and organizational performance.

Table 1: Correlation between Aggressiveness and Organizational Performance

\begin{tabular}{|c|c|c|c|c|}
\hline & & & Aggressiveness & $\begin{array}{l}\text { Organizational } \\
\text { Performance }\end{array}$ \\
\hline \multirow{7}{*}{$\begin{array}{l}\text { Kendall's } \\
\text { tau_b }\end{array}$} & Aggressiveness & $\begin{array}{l}\text { Correlation } \\
\text { Coefficient }\end{array}$ & 1.000 & $.658^{* 4}$ \\
\hline & & Sig. (2-tailed) & & .003 \\
\hline & & $\mathrm{N}$ & 99 & 99 \\
\hline & & Correlation & $658^{* 4}$ & 1.000 \\
\hline & Organizational & Coefficient & & \\
\hline & Performance & Sig. (2-tailed) & .003 & \\
\hline & & $\mathrm{N}$ & 99 & 99 \\
\hline
\end{tabular}


The table above establishes a strong, positive correlation between aggressiveness and organizational performance, which was statistically significant $(\tau=0.658, \mathrm{p}=.003)$.

$\mathbf{H o}_{2}$ : There is no correlation between defensiveness and organizational performance.

Table 2: Correlation between Defensiveness and Organizational Performance

\begin{tabular}{|c|c|c|c|c|}
\hline & & & Defensiveness & \begin{tabular}{|l|} 
Organizational \\
Performance
\end{tabular} \\
\hline \multirow{6}{*}{$\begin{array}{l}\text { Kendall's } \\
\text { tau_b }\end{array}$} & Defensiveness & $\begin{array}{l}\text { Correlation } \\
\text { Coefficient }\end{array}$ & 1.000 & $.535^{* 4}$ \\
\hline & & Sig. (2-tailed) & & .001 \\
\hline & & $\mathrm{N}$ & 99 & 99 \\
\hline & Orranizational & Correlation & $.535^{* *}$ & 1.000 \\
\hline & Performance & Sig. (2-tailed) & .001 & \\
\hline & & $\mathrm{N}$ & 99 & 99 \\
\hline
\end{tabular}

*** Correlation is significant at the 0.01 level (2-tailed)

The table above establishes a strong, positive correlation between defensiveness and organizational performance, which was statistically significant $(\tau=0.535, \mathrm{p}=.001)$.

Ho3: There is no correlation between futurity and organizational performance.

Table 3: Correlation between Futurity and Organizational Performance

\begin{tabular}{|lll|r|r|}
\hline & & Futurity & $\begin{array}{l}\text { Organizational } \\
\text { Performance }\end{array}$ \\
\hline & Futurity & Correlation & 1.000 & $.736^{*+}$ \\
& & Coefficient & & .000 \\
Kendall's & & Sig. (2-tailed) & 99 & 99 \\
tau_b & N & $.736^{*+}$ & 1.000 \\
& & Correlation & & \\
& Organizational & Coefficient & .000 & 99 \\
& Performance & Sig. (2-tailed) & & \\
& & $\mathrm{N}$ & 99 & \\
\hline
\end{tabular}

*** Correlation is significant at the 0.01 level (2-tailed)

The table above establishes a strong, positive correlation between futurity and organizational performance, which was statistically significant $(\tau=0.736, \mathrm{p}=.000)$.

Ho4: There is no correlation between proactiveness and organizational performance. 
Table 4: Correlation between Proactiveness and Organizational Performance

\begin{tabular}{|lll|r|r|}
\hline & & Proactiveness & $\begin{array}{l}\text { Organizational } \\
\text { Performance }\end{array}$ \\
\hline & & & 1.000 & $.877^{* *}$ \\
& & & & \\
Kendall's & & Correlation & & .000 \\
tau_b & & Coefficient & 99 & 99 \\
& & $\mathrm{~N}$ & $.877^{* *}$ & 1.000 \\
& Organizational & Correlation & & \\
& Performance & Coefficient & .000 & \\
& & Sig. (2-tailed) & 99 & 99 \\
\hline
\end{tabular}

** Correlation is significant at the 0.01 level (2-tailed)

The table above establishes a strong, positive correlation between pro-activeness and organizational performance, which was statistically significant $(\tau=0.877, \mathrm{p}=.000)$.

Hence, all previous hypotheses were rejected, and the alternate hypotheses stating a positive correlation were accepted.

\section{FINDINGS}

\subsection{Discussions on Findings}

From the four analyses above, innovation strategies have high potentials of enhancing the organizational performance of water packing firms. The analysis reveals that the water packaging sector in Lagos manifests high levels of aggressiveness, defensiveness, futurity, and pro-activeness.

All four hypotheses were rejected on the grounds that there is a strong positive correlation between innovation strategies (aggressiveness, defensiveness, futurity, and pro-activeness) and organizational performance.

This means that with the higher levels of innovation strategies, organizational performance will be triggered in the water packaging industry. Thus, as businesses push their pricing below competitors' prices while also improving quality, performance \& utility value obtained from current products continually, and are future oriented; they will use their new products approach to gain a competitive advantage over their competitors.

Furthermore, as firms tend to enhance performance, there ought to be quality information gathered about customers, sales to new customers, capturing of increased market share and an increase in overall satisfaction of its customers. 
This is apparent in similar studies conducted in this context, which is tandem with the findings of Karabulut (2015) that 'demonstrated a positive significant relationship between innovation strategies and organizational performance’ (Ahmed, A., \& Othman, I-B. L., 2017).

\section{CONCLUSIONS \& RECOMMENDATIONS}

\subsection{Conclusions}

This study was conducted primarily to empirically investigate the relationship between innovation strategies and organizational performance of water packaging businesses in Lagos State. The study concludes that aggressiveness, defensiveness, futurity and pro-activeness all strengthen organizational performance of water packaging firms in Lagos State. It means all the dimensions of innovation strategies investigated are significant.

Thus, for water packaging firms to enhance performance, they should respond to market demands more quickly than their competitors and be sensitive about the current needs and wants from customers of their products.

Consequently, water packaging businesses in Lagos State of Nigeria should forecast the possibility of changes in the market which can be used to exploit new products and market opportunities.

\subsection{Recommendations}

Based on the foregoing, the study recommends that:

(1) Water packaging firms in Lagos State should see innovation strategies as more important than profit making.

(2) Management should ensure they develop the quality and performance of their products.

(3) Potential and prospective customers should be given more attention than existing customers while retaining current customers.

(4) Management should encourage innovation activities, market leadership. 


\section{REFERENCES}

Abiodun, A. J. (2009). Exploring the relationship between human personal values, strategy dimensions and performance. Annals of University of Bucharest, Economic and Administrative Series 3, 237-248.

Abreu, M., \& Mendes, V. (2002). Commercial bank interest margins and profitability: Evidence from EU countries. Porto Working Paper Series, CISEP, Portugal.

Achtenhagen, L., Naldi, L., \&Melin, L. (2010). Business growth: Do practitioners and scholar really talk about the same thing? Entrepreneurship Theory and Practice, 34(3), 289-316.

Ahmed, A., \& Othman, I-B. L. (2017). Relationship between organizational resources and organizational performance: A conceptualize mediation study. European Online Journal of Natural and Social Sciences, 6(1), 10-27.

Akman, G., \& Yilmaz, C. (2008). Innovative capability, innovation strategy and market orientation: An empirical analysis in Turkish software industry. International Journal of Innovation Management, 12(1), 69-111.

Anthony, S. D., Eyring, M., \& Gibson, L. (2006). Mapping your innovation Strategy, Harvard Business Review, 104-113.

Armstrong S., \& Green, K. C. (2007). Competitor-oriented objectives: The myth of market share. International Journal of Business, 12(1), 116-134.

Banafa, A., Muturi, W., \& Ngugi, K. (2015). The impact of leverage on financial performance of listed non-financial firm in Kenya. International Journal of Finance and Accounting, 4 (7), 1-20.

Barney, J. B. (1991). Firm resources and sustained competitive advantage, Journal of Management, 17(1), 99-120.

Bateman, T., \&Crant, J. M. (1999). Proactive behaviour: Meaning, impact, recommendations. Business Horizons, 42(3), 63-56.

Brynjolfson, E. (1993). The productivity paradox of information technology: review and assessment. Communication of the ACM, 36(12), 67-77.

Calantone, R. J., Cavusgil, S. T., \& Zhao, Y. (2002). Learning orientation, firm innovation capability, and firm performance. Industrial Marketing Management, 31(6), 515-524. 


\section{Article DOI: 10.46654/ij.24889849.b61117}

Celtekligil, K., \& Zafer, A. (2019). Analysis of the effect of innovation strategy and technological turbulence on competitive capabilities and organizational innovativeness in technology firms. Procedia Computer Science, 158, 772-780.

Cherry, H. (2012). Exploring lean production through the diffusion of innovation: Development of a new implementation effectiveness index. Doctoral Dissertation, Trident University International, California, United State of America.

Choi, B. (2002). Knowledge management enablers, processes, and organization performance: An integration and empirical examination. Doctoral dissertation, Division of Management Engineering, Korea Advanced Institute of Science of Technology, Korea.

Davidsson, P., Achtenhagen, L., \&Naldi, L. (2010). Small firm growth. Foundations and Trends in Entrepreneurship, 6(2), 69-166.

Dozier, B. (2016). Impact of staff turnover on organizational performance: A case study of Beitbridge town council. International Energy Policy: Strategic Paper. United Nations.

Enekwe, C. I., Okwo, I. M., \&Ordu, M. M. (2013). Financial ratio analysis as a determinant of profitability in Nigerian pharmaceutical industry. International Journal of Business and Management, 8(8), 107-117.

Engum, M. (2009). Implementing lean manufacturing into newspaper production operations. The Rochester Institute of Technology, 3-6.

Gilbert, J. T. (1994). Choosing an innovation strategy: Theory and practice. Business Horizons, $37(6), 16-21$.

Gërguri S., Rexhepi G., \&Ramadani V. (2013). Innovation strategies and competitive advantages. 20-26.

Hamel, G., \& Prahalad, C. (1996). Competing for the Future. Harvard Business School Press.

Helfat, C. E., \&Peteraf, M. A. (2003). The dynamic resource-based view: Capability lifecycles. Strategic Management Journal, 24, 997-1010.

Henry, A. (2008). Understanding strategic management. Oxford University Press.

Hoopes, D., Madsen, T., \& Walker, G. (2003). Guest editor's introduction to the special issue: Why is there a resource-based view? Toward a theory of competitive heterogeneity. Strategic Management Journal, 24, 889-902. 


\section{Article DOI: 10.46654/ij.24889849.b61117}

Jaworski, B. J., \& Kohli, A. K. (1996). Market orientation: Antecedents and consequences. Journal of Marketing, 57(July), 53-57.

Karabulut, A. T. (2015). Effects of innovation strategy on firm performance: A study conducted on manufacturing firms in Turkey. Procedia-Social and Behavioral Sciences, 195, 13381347.

Katz, B. R., \&Preez, N. D., \& Schutte, C. S. L. (2010). Definition and role of an innovation strategy. [online] [2011-01-02]. Available on Internet: http://www.saiie.co.za/ocs/index.php/saiie/SAIIE10/paper/view/119/72.

Liehr, P., \& Smith, M. J. (1999). Middle range theory: Spinning research and practice to create knowledge for the new millennium. Advances in Nursing Science, 21(4), 81-91.

Makhija, M. (2003). Comparing the resource-based and the market-based views of the firm: Empirical evidence from the Czech privatization. Strategic Management Journal, 24, 433-451.

Miles, R., \& Cameron, K. (1982). Coffin nails and corporate strategies. Prentice-Hall.

Morgan, R. E., \& Strong, C. A. (1998). Market orientation and dimensions of strategic orientation. European Journal of Marketing, 32(11/12), 1051-1073.

Myers, S. C. (2001). Capital structure. Journal of Economic Perspectives, 15(2), 81-102.

O'Regan, N. (2002). Market share: The conduct to future success? European Business Review, 14(4), 287-293.

Odumeru, J. A. (2013). Innovation and organizational performance. Kuwait Chapter of Arabian Journal of Business and Management Review, 2(12), 18-22.

Oduyoye, O., Akinlabi, B. H., \&Gafar, L. K. (2020). Entrepreneurial orientation and profitability of selected water packaging companies in Lagos State, Nigeria. Global Scientific Journal, $8(5), 409-422$.

Oke, A., Walumbwa, F. O. \& Myers, A. (2012), Innovation strategy, human resource policy, and firms' revenue growth: The roles of environmental uncertainty and innovation performance. Decision Sciences, 43(2), 273-302.

Onwughalu, O. O., Okeke, K. E., \& Henry-Chibor, E. (2017). Lean production and its effect in organizations: A study of selected manufacturing firms in Nigeria. Scholarly Journal of Science Research and Essay, 6(4), 85-98. 


\section{Article DOI: 10.46654/ij.24889849.b61117}

Özsomer, A., Calantone, R. J., \& Benedetto, A. D. (1997). What makes firms more innovative? A look at organizational and environmental factors. Journal of Business \& Industrial Marketing, 12(6), 400-441.

Paladino, A. (2009). Financial champions and masters of innovation: Analyzing the effects of balancing strategic orientations. Journal of Product Innovation Management, 26(6), 616626.

Pasiouras, F., \&Kosmidou, K. (2007). Factors influencing the profitability of domestic and foreign commercial banks in the European Union. Research in International Business and Finance, 21, 222-237.

Payal, R., Ahmed, S., \& Debnath, R. M. (2019). Impact of knowledge management on organizational performance: An application of structural equation modeling. VINE Journal of Information and Knowledge Management Systems, 49(4), 510-530.

Penrose, E. T. (1959). The theory of the growth of the firm. Wiley.

Peteraf, M. (1993). The cornerstones of competitive advantage: A resource-based view. Strategic Management Journal, 13, 363-380.

Rauch, A., \&Rijskik, S. A. (2013). The effects of general and specific human capital on longterm growth and failure of newly founded businesses. Entrepreneurship Theory and Practice (3), 923-941.

Robinson, T., Henry, E., Pirie, W., \&Broihahn, M. (2015). International financial statement analysis. (3rd Edition). John Wiley \& Sons, Inc.

Sandvik, I. L., \& Sandvik, K. (2003). The impact of market orientation on product innovativeness and business performance. International Journal of Research in Marketing, 20(4), 355-376.

Sarkissian, S., \&Schill, M. (2010). Cross-listing waves. Munich Personal RePEc Archive, Paper No. 27545. Retrieved from http://mpra.ub.uni-muenchen.de/27545

Segaro, E. L., Larimo, J., \& Jones, M. V. (2014). Internationalization of family small and medium sized enterprises: The role of stewardship orientation, family commitment culture and top management team. International Business Review, 23(2), 381-395.

Staffold, D., \& Miles, L. (2013). Integrating culture after a merger. Brain \& Company.

Stambaugh, J., Yu A., \& Dubinsky, A. (2011). Before the attack: A typology of strategies for competitive aggressiveness. Journal of Management Policy and Practice, 12, 49-63 
Strecker, N. (2009). Innovation strategy and firm performance: An empirical study of publicly listed firms. Gabler Verlag.

Teece, D. J., Peteraf, M., \&Leih, S. (2016). Dynamic capabilities and organizational agility: risk, uncertainty, and strategy in the innovation economy. California Management Review, 58(4), 13-35.

Teece, D. J., Pisano, G., \&Schuen, A. (1997). Dynamic capabilities and strategic management. Strategic Management Journal, 18(7), 509-533.

Upadhaya, B., Munor, R., \& Blount, Y. (2014) Association between performance system and organizational effectiveness. International Journal of Operation \& Production Management, 34(7), 2-20.

Vazquez, R., Santoz, M. L., \& Alvarez, M. L. (2001). Market orientation, innovation and competitive strategies in industrial firms. Journal of Strategic Marketing, 9, 69-90.

Venkatraman, N. (1989). Strategic orientation of business enterprises: The construct, dimensionality, and measurement. Management Science, 35(8), 942-962.

Venkatraman, N., \&Ramanujam, V. (1986). Measurement of business performance in strategy research: A comparison of approaches. Academy of Management Review, 11, 801-814.

Wernerfelt, B. (1995). The resource-based view of the firm: Ten years after. Strategic Management Journal, 16(3), 171-174.

Yazdanfar, D. (2013). Profitability determinants among micro firms: Evidence from Swedish data. The International Journal of Managerial Finance, 9(2), 150-160. 